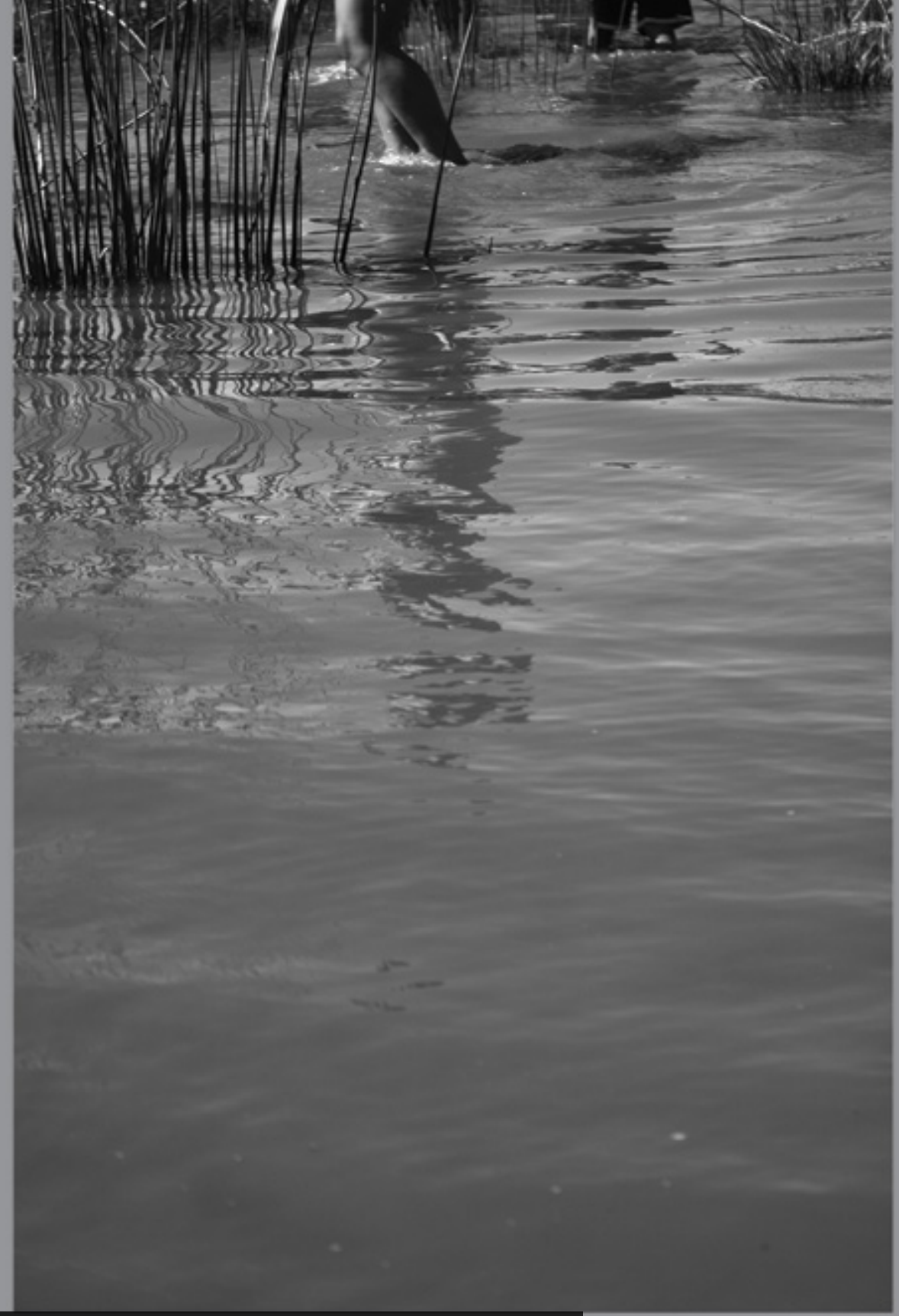

\title{
SECCIÓN HOMENAJE
}

REDEA. DERECHOS EN ACCIÓN | Año 2 № 4 | Invierno 2017 PORTADA: SERGIO MICHAEL ÁLVAREZ | DE LAS MÁRGENES Y OTRAS ORILLAS. 


\section{Soledad}

Estoy sentado en el patio de mi casa.

Nada sucede.

Las hojas como pájaros.

Los pájaros como un destino huidizo e inasible.

Es este otoño interminable. Esta indefinición del tiempo que todo lo abraza. Que todo lo puede.

¿Qué mundo es este?

¿Qué reino?

Convulsiona el cielo.

Las hojas se llevan a los pájaros envolviéndolos en remolinos ensortijados, retorcidos de anhelos indescriptibles.

Crepitan los tallos y los troncos, luego son astillas, aserrín, aire turbio de maderas.

Las gargantas de agua azulina chorrean su silencio hacia una palabra escondida.

La mirada de mis ojos, se clava en un punto indefinido.

Sigo sentado en el patio de mi casa. 